\title{
Gender differences in overplacement in familiar and unfamiliar tasks: Far more similarities*
}

\author{
Pablo Brañas-Garza \\ LoyolaBehLAB \\ Economics Department \\ Universidad Loyola Andalucía, \\ Spain
}

\author{
Ernesto Mesa-Vázquez \\ ERICES \\ Economic Analysis Dep. \\ Universidad de Valencia, \\ Spain
}

\author{
Noelia Rivera-Garrido \\ LoyolaBehLAB \\ Economics Department \\ Universidad Loyola Andalucía, \\ Spain
}

\begin{abstract}
This paper explores gender differences in overplacement in two independent and unrelated tasks. The first measures performance via Raven's Progressive Matrices test, the second in a video presentation assessed by external judges. While in the first task, we expected participants to have prior knowledge about their own experience in similar tasks, we did not expect them to have experience of the second task. Therefore, the latter seems an ideal environment in which to test overplacement given that participants had no ex-ante information with which to make performance predictions. In both cases, participants received monetary incentives depending on the accuracy of their predictions regarding their own performance compared to other participants. We analyzed overplacement - whether participants expect to outperform their actual performance compared to the entire sample - and in/out-group overplacement- whether the participants expect to outperform participants of the same and the opposite sex. Results show that there are no gender differences in any task except in Raven's Progressive Matrices for out-group overplacement.
\end{abstract}

Keywords: Overplacement, gender, experiments, in-group, out-group

JEL Codes: D84, D91, J16

(*) We thank Coralio Ballester, Ramón Cobo-Reyes and Penélope Hernández for their help when running the experiments. We also thank participants at the ECREEW 2019 and LoyolaWEB 2020 Conferences. This work was supported by the Spanish Ministry of Economy and Competitiveness (PGC2018-093506B-I00), and the Excelencia-Junta (PY-18-FR-0007).

(**) Corresponding author: Noelia Rivera-Garrido, Economics, Universidad Loyola Andalucía (nriverag@uloyola.es) 


\section{Introduction}

Overconfidence refers to a phenomenon in which individuals overestimate their abilities in comparison to their actual performance. This can have both positive and negative implications. From a medical point of view, it could be beneficial given that overconfidence is known to be protective of health (Taylor et al., 2000). Furthermore, there is also evidence that overconfidence improves an individual's performance (Compte and Postlewaite, 2004), as well as their motivation and welfare (Benabou and Tirole, 2002). However, it could also carry negative consequences. Among other effects, overconfidence has been found to be one of the factors that explains trading decisions when expected earnings are negative (Odean, 1999), academic failure (Cabrera et al., 2017), and wars (Johnson, 2009). Given the aforementioned, research into overconfidence is crucial from an economic point of view.

The most general belief is that overconfidence is universal. According to De Bondt and Thaler (1995), "perhaps the most robust finding in the psychology of judgment is that people are overconfident". However, the level of confidence differs across populations and depends on many factors. Muthukrishna et al. (2018) cite many articles that show that the level of confidence varies across individuals given that it depends on factors such as age, gender, and population. Moreover, they find that overconfidence also depends on cultural traits. The kind of task performed also has an impact. Males are more confident performing so-called "masculine" tasks than females (Barber and Odean, 2001).

Although overconfidence may manifest itself in different ways (see Moore et al., 2008), this paper focuses on overplacement of one's performance relative to others, in other words, the belief that one's performance is better than that of others. Specifically, we examine gender differences in overplacement and, in particular, when females and males compare themselves to others of the same sex (in-group) and to others of the opposite sex (out-group).

Overconfidence has been studied in several ways. Moore and Healy (2008) developed a theory of confidence that relates to all of them. They show that there is a negative relationship between overconfidence and overplacement. Those individuals who overperform tend to underestimate their own performance (underconfidence), while underestimating others even more (overplacement). In contrast, individuals who underperform tend to overestimate their own performance (overconfidence) and overestimate 
others' performance even more (underplacement). Similar findings were reported by Cabrera et al. (2017).

Closer to our study, literature on performance relative to others finds that most people think they are above average (Alicke and Govorun, 2005). In addition, research on gender differences in overconfidence have, to date, found diverse results. While some studies find that overconfidence is higher in males (Ring et al., 2016; Soll et al., 2004; Barber et al., 2001; Bucher et al., 2016; Healy et al., 2007, Dahlbom, 2011; Jakobsson et al., 2013), others find that there are no gender differences (Neyse et al., 2016; Biais et al., 2005; Nekby, 2008; Zhang et al., 2019; Deaves et al., 2009). ${ }^{1,2}$ To our knowledge, there is no evidence of overplacement in females. Therefore, given the varied results, we believe further analysis is needed to determine whether performance predictions in females could lead to overplacement.

Overconfidence is usually measured through written questionnaires. Some examples are the Cognitive Reflection Test (CRT) (Ring et al., 2016), the Elicitation of Genuine Overconfidence (EGO) (Muthukrishna et al., 2018), interval and two-choice questionnaires (Soll et al., 2004), financial questionnaires (Bucher et al., 2016), Raven's Progressive Matrices test (Zhang et al, 2019), psychological questionnaires (Bianis et al., 2005), and mathematic tests (Dahlbom, 2011). ${ }^{3}$ However, overconfidence has not been studied in environments in which participants have no previous experience.

In line with the abovementioned literature, we asked participants to complete Raven's Progressive Matrices (RPM) test. This popular test measures individuals' abilities using multiple choice questions. However, individuals might have experience in similar tests and make predictions based on prior knowledge. Consequently, participants' selfassessment or performance predictions might be related to their own previous experience rather than their performance in the test.

Unlike other studies, we avoided this issue by implementing a new task in which the participant was expected to have had no previous experience. Specifically, we asked

\footnotetext{
${ }^{1}$ See Moore \& Dev (2018) for further discussion on this point. 2 Overconfidence improves professional success (Kanter, 2004). If males are more overconfident than females, primarily due to culture factors, it could explain why females have less presence in the labor market (Antecol, 2001), and the variation in the gender wage gap (Antecol, 2000).

${ }^{3}$ Overconfidence has also been measured through scrabble tournaments (Healy et al., 2007) and sporting events (Nekby, 2008, among others).
} 
participants to make a video presentation (individual task). Each participant entered a dedicated room and read the sentence "My name is xxxx and I was born in xxx. My code is $x x x$ " in front of a professional video-camera operator who recorded their presentation. All videos were then assessed by an external panel of judges. Afterward, participants were asked to assess their own performance. Given that participants had no previous experience, this task seemed the most appropriate for assessing gender differences in performance predictions.

Our design enabled us to build three measures of overplacement for each task (overplacement, in- and out-group). By controlling for risk aversion, cognitive abilities, and self-reported health, we found no gender differences in overplacement in the RPM test. However, in the video task, where participants had no previous experience, we found in-group overplacement in females but no evidence of overplacement in males in any of the measures.

We found no evidence of gender differences in overplacement and in-group overplacement in either the RPM test or the video task. However, in out-group overplacement - when participants compare themselves to the opposed sex - we found gender differences in favor of females in the RPM test. In contrast, we found no evidence for out-group overplacement in the video task once we controlled for observable characteristics.

The rest of the paper is organized as follows. Section 2 describes the experiment design. Section 3 explains the sample. Sections 4 presents the results. And lastly, section 5 discusses the results and presents the conclusion.

\section{Experiment Design}

The two-part experiment was conducted at the Experimental Economics Lab (EGEO) at the University of Granada in 2009 on subsequent days.

In the first part, participants completed the 60-item RPM test at the EGEO Lab. The RPM test is a popular nonverbal test that measures reasoning abilities and has been in 
use for decades. It comprises 60 multiple choice questions, listed in order of difficulty 4 . The test was originally developed by John C. Raven in 1936 (Raven, 1936).

After the lab session, participants were invited to a dedicated room where they were asked to give a short presentation of themselves in front of a professional camera operator who recorded their speech. The video was assessed by a panel of 20 external judges who had no relationship with the participants (see appendix for details).

It is important to mention that participants received no incentives for the video or the RPM tests and, more importantly, were completely unaware of the "performance prediction" task that came afterward.

The second part of the experiment followed the day after. The participants received an email asking them to make predictions of their own performance. They were asked to make 6 predictions of their performance in deciles $(0 \%, 10 \%, \ldots, 90 \%, 100 \%)$, which were subject to monetary consequences. They were informed that one out of six predictions would be chosen for real payment. Participants making accurate predictions in the randomly chosen guess would get $€ 20$ ( $€ 0$ otherwise).

The precise questions that participants were presented with in the computer interface were the following (see appendix for a copy of the computer screens). Note that in Task 1 and 2, participants were asked to compare themselves to the entire sample (regardless of gender) while Tasks 3-6 use a specific gender sub-sample as a reference group.

- Task 1: The participant is asked to indicate the decile in which they believe they are placed in the RPM test.

- Task 2: The participant is asked to indicate the decile in which they believe they are placed in the video task.

- Task 3: The participant is asked to indicate the decile in which they believe they are placed in the RPM test when compared to females.

- Task 4: The participant is asked to indicate the decile in which they believe they is placed in the video task when compared to females.

- Task 5: The participant is asked to indicate the decile in which they believe they are placed in the RPM test when compared to males.

\footnotetext{
${ }^{4}$ In each test item, the participant is asked to identify the missing element that completes a pattern. Many patterns are presented in the form of a $6 \times 6,4 \times 4,3 \times 3$, or $2 \times 2$ matrixes.
} 
- Task 6: The participant is asked to indicate the decile in which they believe they are placed in the video task when compared to males.

Using this data, we calculated three measurements of overplacement for each task:

- Overplacement: focuses on the entire sample.

- In-group overplacement: focuses on the own-gender sample.

- Out-group overplacement: focuses on the opposite-gender sample.

We included some additional variables as controls: age, a Holt-Laury (2002) test (with hypothetical payments) to measure individual risk aversion; the Cognitive Reflection Test (CRT) (see Frederick, 2005 and Brañas-Garza et al., 2019 for a meta-analysis), and self-reported level of health. None of these additional measurements was incentivized. ${ }^{5}$

A show-up fee was not provided. A total of 15 out of 125 participants made accurate predictions in the randomly selected guess and earned the $€ 20$ prize. On average, participants earned $€ 2.40$ for a 15 -minute online session.

It is important to mention two significant features of our design. First, all the participants followed the same identical sequence: participants always performed the RPM test before the video task. The first question asked the participant to compare themselves to the entire sample, then just to females, and, lastly, just to males. This implies that we cannot disregard potential order effects. However, it is important to emphasize that the participants did not receive any feedback during the experiment.

Second, at the time the participants were performing both the RPM test and the video task they were unaware of the second stage (performance predictions) and, most importantly, by the time they were making predictions their performance had ended. Hence, participants could not compare themselves to the opposite sex during the performance only during the evaluation. Both features of our design differentiate our study from other gender competition experiments (see for example Gneezy and Muriel, 2003; Niederle and Vesterlund, 2007; Gneezy, 2009) given that, regardless of sex, the participants could not anticipate that afterward they would be comparing themselves to other participants of the same and the opposite sex.

\footnotetext{
${ }^{5}$ Brañas-Garza et al. (2020) shows that hypothetical Between Random Incentive Subjects (BRIS) and monetary incentives do not generate different outcomes in the Holt-Laury task.
} 


\section{Sample and participants' performance}

A total of 125 participants (out of 188) entered the website to participate in the second part of the experiment. This indicates a 33\% level of attrition. It is important to mention that those who decided to opt for the second stage performed slightly better in the RPM test than those who did not (although it was not statistically significant at the usual significance levels, $p=0.086$ ). However, this was not the case for the video task ( $p=$ 0.916). In view of these results, we can therefore confirm that there is no self-selection bias in the sample.

Of the 125 who participated in the second part, 120 participants completed all six tasks (predictions). The main descriptive statistics are shown in Table 1.

Table 1: Summary Statistics

\begin{tabular}{lccccc}
\hline & N & Mean & Sd & Min & Max \\
\hline Raven Actual & 120 & 6.050 & 2.898 & 1 & 10 \\
Video Actual & 120 & 5.733 & 2.765 & 1 & 10 \\
Raven Predicted & 120 & 7.158 & 1.730 & 1 & 10 \\
Video Predicted & 120 & 5.975 & 2.019 & 1 & 10 \\
Female & 120 & 0.558 & 0.499 & 0 & 1 \\
Risk & 120 & 4.575 & 1.482 & 1 & 7 \\
CRT & 120 & 0.375 & 0.581 & 0 & 2 \\
Health & 120 & 3.692 & 0.797 & 2 & 5 \\
\hline
\end{tabular}

Actual deciles in the RPM test and the video task were built using a conservative definition. In other words, if the participant's score fell between two deciles, the individual was assigned to the higher decile. This is important as it avoids misclassifying participants' overplacement score. Therefore, the mean value for Raven Actual and Video Actual in Table 1 is higher than 5.

Overall, we observed higher predictions for the RPM test than for the video task. All in all, the participants are risk averse, not particularly good at performing the CRT (the mean is 0.375 out of 3 ) but healthy - given that the mean is 3.692 out of 5 . For the purpose of this study, it is also important to mention that the sample is quite gender balanced ( $55.8 \%$ female).

We found gender differences in performance in the RPM test $(\hat{\beta}=-1.566, p=0.003)$ in favor of males $($ mean females $=5.358$, mean males $=6.924)$. Figure 1 Panel C shows 
these differences. There is no consensus as to why females underperform on cognitive ability tasks (Hedges et al., 1995; Hyde et al., 2008).

We also found gender bias in the overall expected performance of the RPM test $(\hat{\beta}=$ 0.933, $p=0.003$ ) in favor of males who rate themselves better than females rate themselves $($ mean females $=6.746$, mean males $=7.679)$. These expectations refer to Task 1, where participants compare themselves to the entire sample (see also Figure 1 Panel D).

However, the actual performance of the video task is different. We found no gender bias in the video task $(\hat{\beta}=-0.274, p=0.591)$. The mean for females is 5.611 and for males, 5.887. Notwithstanding, we did find that females were more overconfident than males in their expected performance for the video task $(\hat{\beta}=0.766, p=0.038$, mean females $=6.313$, mean males $=5.547)$ when comparing themselves to the entire distribution (Task 1).

Although the RPM test and video task are independent and ex-ante uncorrelated, we still needed to test whether this was the case. Confirming our expectations, we found that performance in the RPM test and the video task were uncorrelated $(\rho=0.0352, p$ $=0.702)$.

In sharp contrast, we found that participants' predictions regarding their own performance in both the RPM test and the video task were highly correlated $(\rho=0.220$, $p=0.016$ ). That means that those who believed they would get a high or low score in the RPM test also believed they would get the same result in the video task.

It is important to mention that overplacement is defined as overconfidence in one's performance relative to others. Consequently, high predictions are not necessarily evidence of overplacement given that predications should be compared to the actual performance.

In the following sections, we explore in detail the gender differences in overplacement, in/out group overplacement in both the RPM test and the video task. 


\section{Results}

\subsection{Overplacement in Raven's Progressive Matrices}

Figure 1 gives a general view of overplacement: beliefs regarding one's own performance relative to others (entire sample). Panel A shows the cumulative distribution of the predicted values and the uniform distribution (diagonal). Panel B plots both actual and predicted performance at an individual level for both females and males. Dots placed diagonally show participants with no errors $($ actual $=$ predicted $)$ while those below the diagonal reflects overplacement $($ actual $<$ predicted $)$.

Figure 1: Actual and predicted performance in the RPM test: Gender differences
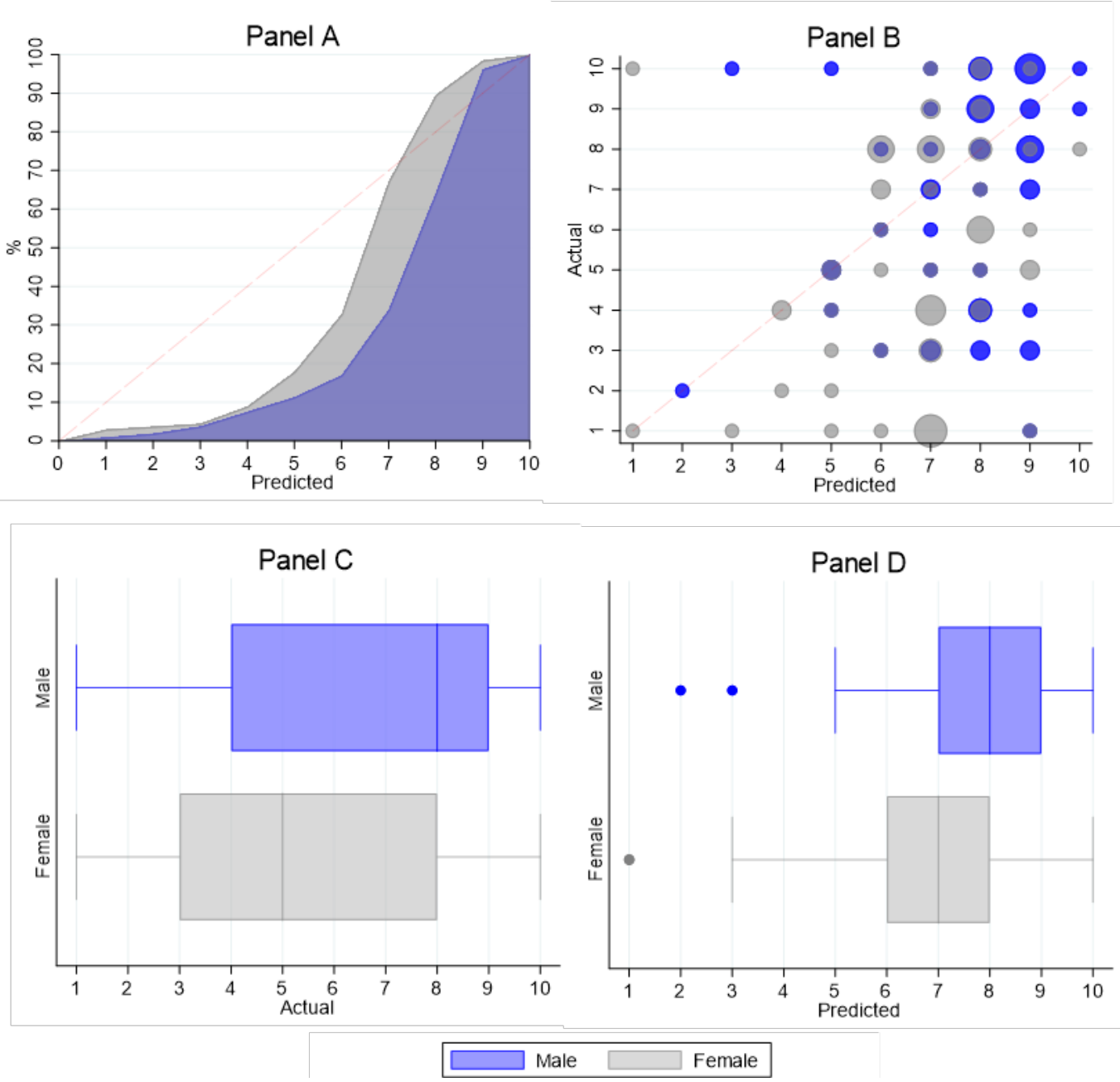

Figure $\mathrm{C}$ and D show the box plot graph for actual and predicted performances, respectively. It shows that males score higher than females. Similar values are observed for predictions: there is clear gender bias in favor of more overconfident males. 
However, these differences might be compensated by performance. We analyze these differences in detail in this section. Figure A1 (appendix) shows the same analysis as Figure 1 for in- and out-group data.

As previously mentioned, high predictions are not necessarily evidence of overplacement. We need to test whether predictions are higher than actual performance, in other words, overplacement appears when predicted - actual $>0$.

Table 2 shows the econometric analysis. We used two types of models. On the left, we consider discrete models where we study whether the participant evaluates themself as better than the comparison group (overplacement $=1$, otherwise $=0$ ).

On the right, we estimate the continuous version of overplacement where the intensity is also measured (ranging from 0 to 8 ); we are therefore considering degrees of overplacement. For discrete and continuous models, we studied overplacement, in- and out-group overplacement in Table 2 . We used models with and without controls. To test the robustness of our results, we expanded the analysis using a less strict definition of overplacement where we allowed participants to make +1 decile error in their predictions. Table A1 (appendix) provides this analysis.

Our results indicate that there are no gender differences in overplacement. The same result is replicated for the continuous version of the model (on the right). The model with errors (Table A1, appendix) shows that females are more prone to exhibit overall overplacement $(p<0.05)$.

We did not observe gender bias in in-group overplacement either. Again, alternative models such as the continuous (on the right) or models with errors (Table A2) provide the very same results. When females or males compare themselves to their own sex there is no differences in overplacement.

In sharp contrast, we did observe gender differences in out-group overplacement. When participants compare themselves to participants of the opposite sex, we found that females exhibit overplacement. The result is fairly strong $(p<0.01)$ regardless of the specification (discrete, continuous, or with errors).

We therefore conclude:

Result 1: There is no gender bias in overplacement and in-group overplacement in the RPM test. However, we observe greater out-group overplacement in females. 
Table 2: Gender differences in overplacement using the RPM test

\begin{tabular}{|c|c|c|c|c|c|c|c|c|c|c|c|c|}
\hline & \multicolumn{6}{|c|}{ Discrete $^{1}$} & \multicolumn{6}{|c|}{ Continuous $^{2}$} \\
\hline & \multicolumn{2}{|c|}{ Full sample } & \multicolumn{2}{|c|}{ In-group } & \multicolumn{2}{|c|}{ Out-group } & \multicolumn{2}{|c|}{ Full sample } & \multicolumn{2}{|c|}{ In-group } & \multicolumn{2}{|c|}{ Out-group } \\
\hline & (1) & (2) & (1) & (2) & (1) & $(2)$ & (1) & $(2)$ & (1) & $(2)$ & (1) & $(2)$ \\
\hline \multirow[t]{2}{*}{ Female } & 0.114 & 0.139 & -0.037 & -0.028 & $0.260 * *$ & $0.272 * *$ & 0.525 & 0.465 & -0.398 & -0.509 & $1.129 * *$ & $1.323 * *$ \\
\hline & $(0.092)$ & $(0.09)$ & $(0.091)$ & $(0.098)$ & $(0.087)$ & $(0.091)$ & $(0.388)$ & $(0.407)$ & $(0.423)$ & $(0.445)$ & $(0.402)$ & $(0.422)$ \\
\hline \multirow[t]{2}{*}{ Age } & & 0.033 & & 0.023 & & 0.029 & & 0.077 & & 0.073 & & 0.150 \\
\hline & & $(0.02)$ & & $(0.022)$ & & $(0.02)$ & & $(0.090)$ & & $(0.098)$ & & $(0.093)$ \\
\hline \multirow[t]{2}{*}{ Averse } & & 0.047 & & 0.014 & & 0.017 & & 0.204 & & 0.221 & & 0.192 \\
\hline & & $(0.03)$ & & $(0.033)$ & & $(0.031)$ & & $(0.138)$ & & $(0.151)$ & & $(0.143)$ \\
\hline \multirow[t]{2}{*}{$C R T$} & & -0.07 & & -0.101 & & $-0.178^{*}$ & & -0.612 & & -0.701 & & -0.568 \\
\hline & & $(0.08)$ & & $(0.085)$ & & $(0.079)$ & & $(0.354)$ & & $(0.387)$ & & $(0.367)$ \\
\hline \multirow[t]{2}{*}{ Health } & & 0.106 & & 0.045 & & 0.094 & & 0.348 & & 0.286 & & 0.331 \\
\hline & & $(0.06)$ & & $(0.059)$ & & $(0.055)$ & & $(0.245)$ & & $(0.286)$ & & $(0.254)$ \\
\hline \multirow[t]{2}{*}{ Constant } & $0.453 * * *$ & -0.87 & $0.604 * * *$ & -0.107 & $0.472 * * *$ & -0.541 & $1.415 * * *$ & -2.258 & $2.189 * * *$ & -1.189 & $1.359 * * *$ & -3.884 \\
\hline & $(0.069)$ & $(0.56)$ & $(0.068)$ & $(0.564)$ & $(0.065)$ & $(0.522)$ & $(0.290)$ & $(2.338)$ & $(0.316)$ & $(2.557)$ & $(0.300)$ & $(2.421)$ \\
\hline Observations & 120 & 120 & 120 & 120 & 120 & 120 & 120 & 120 & 120 & 120 & 120 & 120 \\
\hline R-squared & 0.013 & 0.08 & 0.001 & 0.028 & 0.07 & 0.143 & 0.015 & 0.086 & 0.007 & 0.076 & 0.081 & 0.148 \\
\hline
\end{tabular}

Note: (1) The dependent variable is a dummy equal to 1 if overplacement in the RPM test and 0 otherwise. (2) The dependent variable is the degree of overplacement (in number of deciles) in the RPM test. Standard errors in parentheses. ${ }^{* * *} \mathrm{p}<0.001, * * \mathrm{p}<0.01,{ }^{*} \mathrm{p}<0.05$ 
In sum, Result 1 indicates that in a task where both females and males have previous experience, and therefore prior knowledge, there are gender differences in overplacement that contrast with several papers in existing literature. Similarly, no effects were found for in-group. In sharp contrast to existing literature, we found that females and not males are more likely to exhibit overconfidence when comparing themselves to the opposite sex.

\subsection{Overplacement in the Video Task}

Before discussing the results, it is important to remember that this task is very different to the RPM test. First, in the video task, participants had to perform in front of a third party (a camera operator) and second, they had no experience in this sort of activity. Therefore, we expected participants to be completely blind in the evaluation of this task. Blind in the sense that they had no previous experience and therefore no prior knowledge with which to compare themselves to other people. In other words, the video task is the perfect environment in which to study unadulterated overconfidence.

Figure 2 explores overplacement of one's performance relative to others and gender differences in performance and predictions in the video task. Identical analysis was replicated for in- and out-group comparisons in Figure A2 in the Appendix.

As in Figure 1, Panel A show the cumulative distribution of the actual performance for both males and females, and the uniform distribution (diagonal). Panel B plots the pair (actual, predicted) at an individual level. Panels C and D show the box plot graph for actual and predicted performance for females and males, respectively. In contrast to the RPM test, we found that the vast majority predict similar values as their actual performance, mostly in the case of males.

We proceeded with the video task in the same way as in the RPM test. Table 3 shows two types of regressions: discrete and continuous overplacement. Table A2 (appendix) repeats the analysis allowing the participant to make errors ( +1 decile). In both the discrete and continuous models, we studied the overplacement, in- and out-group overplacement. As before, we ran models with and without controls.

We did not observe gender differences in overplacement in the discrete model or in the continuous model. Identically, the model with errors provides the same lack of effect. 
No gender differences were found in in-group overplacement. No significant differences were observed for the discrete, continuous, or errors specifications in the appendix.

Figure 2: Actual and predicted performance in the video task: Gender differences
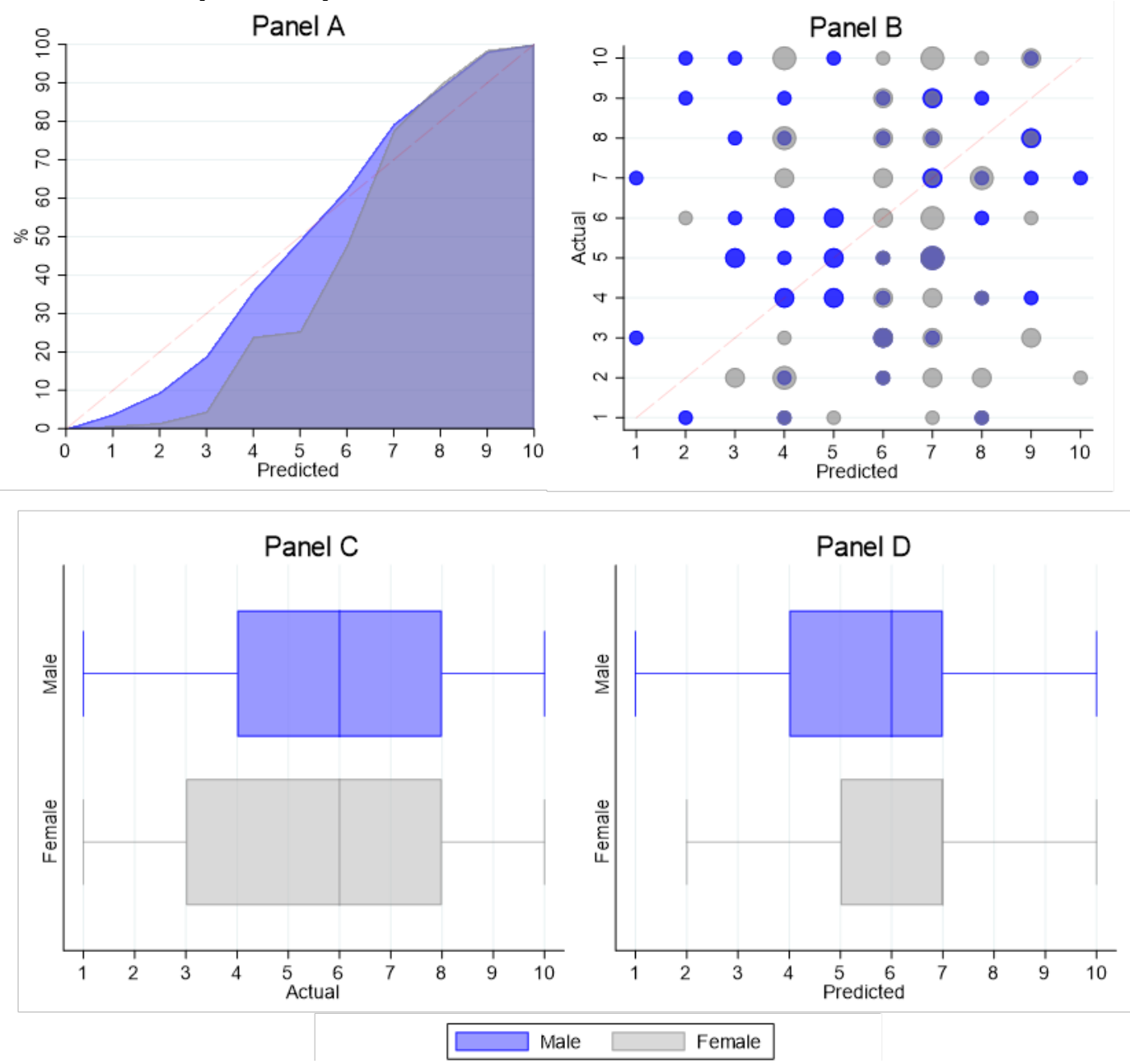

And lastly, we did not observe any gender differences in out-group overplacement (on the left). However, when considering the continuous version of overplacement (on the right), we observed gender differences in favor of females in out-group overplacement. These differences disappear when controlling for individual characteristics. In addition, no gender differences were found when considering a more flexible definition of overplacement in the appendix.

Therefore, we conclude:

Result 2: There is no gender bias in overplacement, in-group and out-group overplacement in the video task. 
Table 3: Gender differences in overplacement in the video task

\begin{tabular}{|c|c|c|c|c|c|c|c|c|c|c|c|c|}
\hline \multirow{3}{*}{$\begin{array}{l}\text { Model } \\
\text { Specification }\end{array}$} & \multicolumn{6}{|c|}{ Discrete $^{1}$} & \multicolumn{6}{|c|}{ Continuous $^{2}$} \\
\hline & \multicolumn{2}{|c|}{ Full sample } & \multicolumn{2}{|c|}{ In-group } & \multicolumn{2}{|c|}{ Out-group } & \multicolumn{2}{|c|}{ Full sample } & \multicolumn{2}{|c|}{ Out-group } & \multicolumn{2}{|c|}{ Out-group } \\
\hline & (1) & (2) & (1) & (2) & (1) & (2) & (1) & (2) & (1) & (2) & (1) & (2) \\
\hline \multirow[t]{2}{*}{ Female } & 0.148 & 0.162 & 0.061 & 0.078 & 0.136 & 0.146 & $0.716^{*}$ & 0.708 & 0.261 & 0.195 & $0.847 *$ & 0.803 \\
\hline & $(0.092)$ & $(0.1)$ & $(0.091)$ & $(0.09)$ & $(0.091)$ & $(0.1)$ & $(0.354)$ & $(0.384)$ & $(0.385)$ & $(0.416)$ & $(0.399)$ & $(0.432)$ \\
\hline \multirow[t]{2}{*}{ Age } & & 0.009 & & 0.025 & & 0.019 & & 0.018 & & 0.041 & & 0.054 \\
\hline & & $(0.02)$ & & $(0.02)$ & & $(0.02)$ & & $(0.085)$ & & $(0.092)$ & & $(0.095)$ \\
\hline \multirow[t]{2}{*}{ Averse } & & $0.069^{*}$ & & $0.077 *$ & & $0.072 *$ & & 0.099 & & 0.152 & & 0.112 \\
\hline & & $(0.03)$ & & $(0.03)$ & & $(0.03)$ & & $(0.130)$ & & $(0.141)$ & & $(0.146)$ \\
\hline \multirow[t]{2}{*}{$C R T$} & & 0.045 & & 0.007 & & -0.02 & & 0.245 & & 0.052 & & -0.166 \\
\hline & & $(0.08)$ & & $(0.08)$ & & $(0.08)$ & & $(0.334)$ & & $(0.362)$ & & $(0.376)$ \\
\hline \multirow[t]{2}{*}{ Health } & & $0.116^{*}$ & & $0.113^{*}$ & & $0.119^{*}$ & & -0.059 & & -0.089 & & 0.008 \\
\hline & & $(0.06)$ & & $(0.06)$ & & $(0.06)$ & & $(0.231)$ & & $(0.251)$ & & $(0.260)$ \\
\hline \multirow[t]{2}{*}{ Constant } & $0.434 * * *$ & -0.53 & $0.566^{* * *}$ & -0.78 & $0.491 * * *$ & -0.69 & $1.075 * * *$ & 0.348 & $1.679 * * *$ & 0.426 & $1.377 * * *$ & -0.274 \\
\hline & $(0.068)$ & $(0.55)$ & $(0.068)$ & $(0.54)$ & $(0.068)$ & $(0.55)$ & $(0.264)$ & $(2.20)$ & $(0.288)$ & (2.391) & $(0.298)$ & $(2.483)$ \\
\hline Observations & 120 & 120 & 120 & 120 & 120 & 120 & 120 & 120 & 120 & 120 & 120 & 120 \\
\hline$R$-squared & 0.022 & 0.088 & 0.004 & 0.094 & 0.019 & 0.099 & 0.033 & 0.043 & 0.004 & 0.019 & 0.037 & 0.049 \\
\hline
\end{tabular}

Notes: (1) The dependent variable is a dummy equal to 1 if overplacement in the video test and 0 otherwise. (2) The dependent variable is the degree of overplacement (in number of deciles) in the video task. Standard errors in parentheses Standard errors in parentheses. *** $\mathrm{p}<0.001, * * \mathrm{p}<0.01,{ }^{*} \mathrm{p}<0.05$. 
In sum, Result 2 shows that there is no different between females and males in overconfident judgements in a task in which they have no previous experience. Interestingly, the task in which we might expect more overconfidence is precisely the environment where we did not observe any gender bias.

Consequently, if overplacement appears in tasks where participants have experience and prior knowledge (Result 1) and not in tasks where there is absence of prior knowledge (Result 2) then overplacement might be partially explained by history, e.g. personal experience. Indeed, in the case where we did find gender differences, it was due to erroneously predicting others' performance rather than overconfidence in one's own performance. This issue is highlighted in section 4.4.

\subsection{Overplacement across tasks}

In this section, we analyze the number of times a participant makes a prediction which is higher than their actual performance, in other words, when they exhibit overplacement. Given that there are three predictions for the RPM test and another three for the video task, the participants could exhibit overplacement from 0 to 6 times.

Table 4, on the left, explores the number of times the participant shows (discrete) overplacement in the RPM test (none, once, twice, or three times), the video task (from 0 to 3 times) and together (from 0 to 6 times). Table 4 on the right repeats the same analysis but allows participants to make an error of 1 decile in their predictions. Again, we used models with and without controls.

Overall, we did not observe any gender bias. We did not find that females show overplacement more often than males. This does not happen in the RPM test, nor in the video task, or both together. In other words, being more prone to overplacement is not gender biased.

Therefore, we conclude:

Result 3: There is no gender bias in the number of times participants show overplacement.

In short, regardless of the task or previous experience, neither females nor males are more likely to show overplacement than their respective opposite sex. 


\subsection{Further analysis: Overconfidence in the sample}

Results 1 and 2 show that there are no gender differences in overplacement. Only one out of six possible tests (out-group in the RPM test) provided a significant result after controlling for individual characteristics. Indeed, the analysis of the number of times participants exhibit overplacement (Result 3) did not provide any significant gender bias. Hence, we can conclude that there is no gender bias in overplacement, given that 8 out of 9 measurements show no significant effect.

However, our results do not imply absence of overplacement. Results 1 to 3 just indicate that, in general, females do not make more overconfident judgements than males. The absence of gender bias might be due to two possible scenarios:

- Both females and males make accurate predictions of their performances

- Both females and males make the very same types of errors (overconfidence)

Figure 3 compares the average performance for both females and males, and predictions for each comparison (overplacement, in- and out-group). The results for the RPM test are shown at the top. We found that both females and males were overconfident. However, the difference between actual and predicted for males was not statistically different from females in overplacement and in-group overplacement (Result 1).

On the extreme right, we have the only significant result from Table 2 (females exhibiting more out-group overconfidence). Here, we can see that females do not expect to do better than males (in fact their predictions for in-group are higher than for out-group 7.22 and 6.97, respectively). The reason why females appear overconfident in the in-group is that they significantly underperformed in comparison to males (4.64 vs 6.04) yet did not anticipate the magnitude of this difference in performance. Hence, their experience in the task did not help at all. 
Table 4: Gender Differences in number of times showing overplacement

\begin{tabular}{|c|c|c|c|c|c|c|c|c|c|c|c|c|}
\hline \multirow{3}{*}{$\begin{array}{l}\text { Model } \\
\text { Specification }\end{array}$} & \multicolumn{6}{|c|}{ Discrete $^{1}$} & \multicolumn{6}{|c|}{+1 decile $^{2}$} \\
\hline & \multicolumn{2}{|c|}{ Raven } & \multicolumn{2}{|c|}{ Video } & \multicolumn{2}{|c|}{ Raven \& Video } & \multicolumn{2}{|c|}{ Raven } & \multicolumn{2}{|c|}{ Video } & \multicolumn{2}{|c|}{ Raven \& Video } \\
\hline & (1) & (2) & (1) & (2) & (1) & (2) & (1) & (2) & (1) & (2) & (1) & (2) \\
\hline \multirow[t]{2}{*}{ Female } & 0.337 & 0.383 & 0.345 & 0.386 & 0.683 & 0.769 & 0.39 & 0.387 & 0.309 & 0.318 & 0.699 & 0.706 \\
\hline & $(0.243)$ & $(0.26)$ & $(0.258)$ & $(0.27)$ & $(0.383)$ & $(0.39)$ & $(0.245)$ & $(0.26)$ & $(0.247)$ & $(0.27)$ & $(0.365)$ & $(0.39)$ \\
\hline \multirow[t]{2}{*}{ Age } & & 0.085 & & 0.053 & & 0.138 & & 0.084 & & -0 & & 0.082 \\
\hline & & $(0.06)$ & & $(0.06)$ & & $(0.09)$ & & $(0.06)$ & & $(0.06)$ & & $(0.09)$ \\
\hline \multirow[t]{2}{*}{ Averse } & & 0.078 & & $0.218^{*}$ & & $0.295 *$ & & 0.122 & & 0.119 & & 0.241 \\
\hline & & $(0.09)$ & & $(0.09)$ & & $(0.13)$ & & $(0.09)$ & & $(0.09)$ & & $(0.13)$ \\
\hline \multirow[t]{2}{*}{$C R T$} & & -0.35 & & 0.031 & & -0.32 & & -0.31 & & 0.053 & & -0.25 \\
\hline & & $(0.22)$ & & $(0.23)$ & & $(0.34)$ & & $(0.22)$ & & $(0.23)$ & & $(0.34)$ \\
\hline \multirow[t]{2}{*}{ Health } & & 0.245 & & $0.348^{*}$ & & $0.593 *$ & & 0.154 & & 0.222 & & 0.376 \\
\hline & & $(0.16)$ & & $(0.16)$ & & $(0.24)$ & & $(0.16)$ & & $(0.16)$ & & $(0.23)$ \\
\hline \multirow[t]{2}{*}{ Constant } & $1.528 * * *$ & -1.519 & $1.491 * * *$ & -2.004 & $3.019 * * *$ & -3.52 & $1.132 * * *$ & -1.74 & $1.094 * * *$ & -0.27 & $2.226^{* * *}$ & -2.01 \\
\hline & $(0.182)$ & $(1.476)$ & $(0.193)$ & $(1.54)$ & $(0.286)$ & $(2.25)$ & $(0.183)$ & $(1.48)$ & $(0.184)$ & $(1.52)$ & $(0.273)$ & $(2.21)$ \\
\hline Observations & 120 & 120 & 120 & 120 & 120 & 120 & 120 & 120 & 120 & 120 & 120 & 120 \\
\hline$R$-squared & 0.016 & 0.078 & 0.015 & 0.101 & 0.026 & 0.138 & 0.021 & 0.083 & 0.013 & 0.042 & 0.03 & 0.094 \\
\hline
\end{tabular}

Notes: (1) The dependent variable is the number of times showing overplacement. (2) The dependent variable is the number of times showing overplacement if more than 1 deciles of difference. Standard errors in parentheses. $* * * \mathrm{p}<0.001,{ }^{* *} \mathrm{p}<0.01,{ }^{*} \mathrm{p}<0.05$ 
Figure 3: Average performance and predictions across tasks

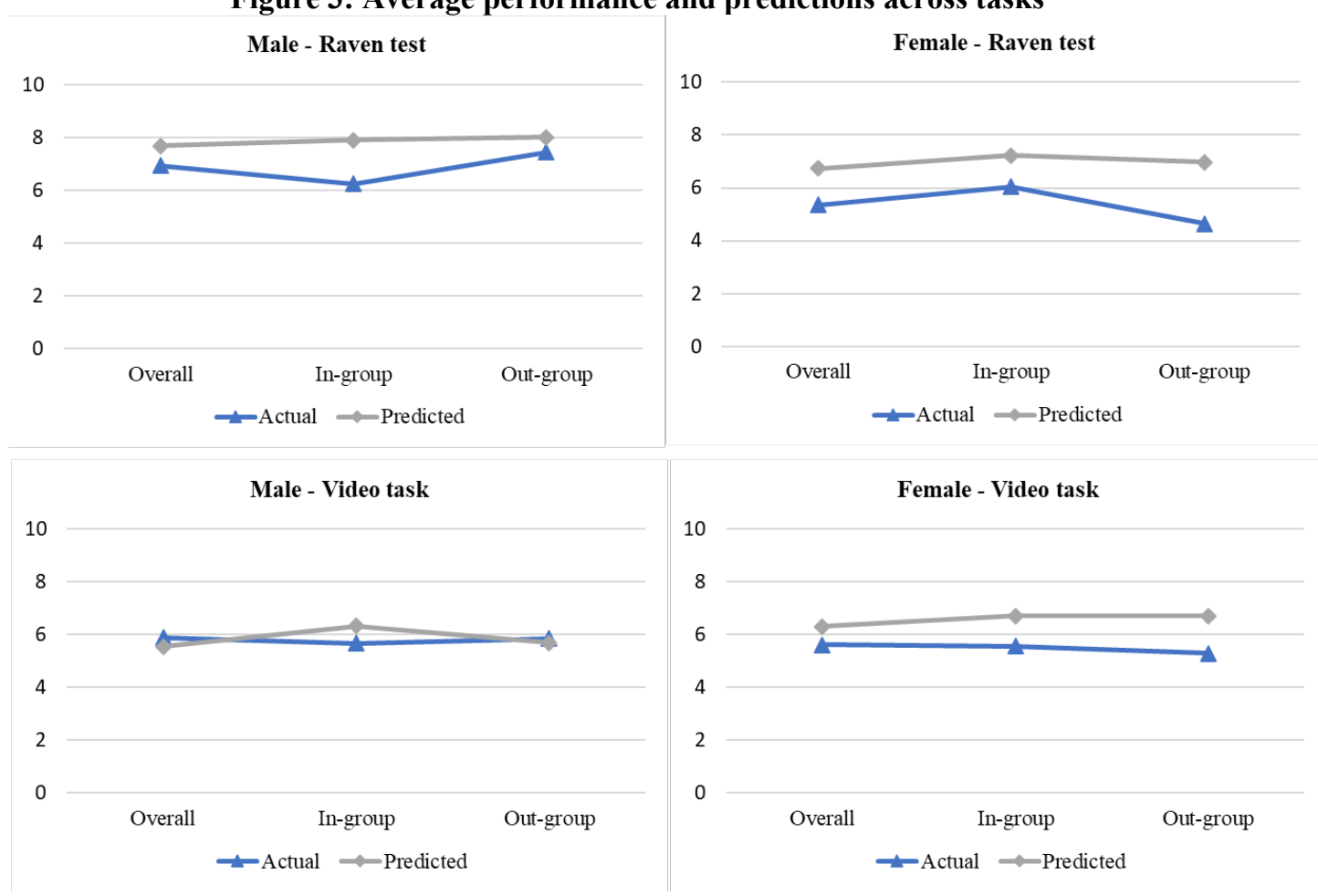

The analysis for the video task is shown in the bottom half of Figure 3. On the left, we observe that males predict their performance quite accurately while females tend to predict better performances. However, the performance of both females and males is very similar (5.61 and 5.89, respectively). Even though females tend to be more overconfident about their performance, differences in overplacement are small and not statistically significant when considering the discrete definition of overplacement. In other words, there is no difference in overplacement between females and males.

Regarding the difference between actual and predicted performance, we did observe some differences. However, they disappear when controlling for individual characteristics as shown in Table 2. When we use the most complete specification, this difference is not statistically significant at $5 \%$ level of significance ( $p$-value $=0.066$ ). Therefore, we can conclude that there are no gender differences in overplacement at the conventional levels of significance in the video task (Result 2).

Therefore, in absence of previous experience in the task, there is no difference between females and males in overplacement.

In sum, we can conclude that there are no gender differences in overplacement and ingroup overplacement in the RPM test because both exhibit similar overplacement. We 
found similar results in the video task. Regarding out-group overplacement, females were more overconfident than males in the RPM test. However, in the video task this difference is not statistically significant. In the latter, the absence of gender differences is due to lower overplacement in the sample.

\section{Discussion}

This paper explores whether females are more or less likely to exhibit overplacement in two unrelated tasks and three dimensions: overplacement, in-group, and out-group. The first task was the 60-item RPM test, a popular nonverbal test that measures reasoning abilities. The second was a video presentation where the participants were asked to introduce themselves. While the RPM test has an objective score, the video was assessed by a panel of 20 external judges with no relationship with the participants. The participation in both tasks was unincentivized.

After the experiment, participants received an email asking them to make predictions of their own performance. They were asked to make six predictions of their performance in deciles with monetary consequences (one random prediction would be chosen and those making accurate predictions would earn $€ 20$ ).

Our design enabled us to build three measures of overplacement for each task (overplacement, in- and out-group). Our regression analysis includes controls for individual age, risk aversion, cognitive abilities, and self-reported health.

From the 120 participants $(55.8 \%$ female) who completed all the tasks, we found no gender differences in overplacement in the RPM test with the exception of out-group where females exhibit higher levels of overplacement in comparison to males. This result was primarily due to the fact that females significantly underestimated the performance of males.

Similarly, in the video task, where participants had no previous experience, we found no gender differences in any measurement of overplacement.

We also found absence of gender differences in the number of times participants exhibit overplacement. This is true for the RPM test, for the video task, and for both tasks together. 
In this study, we performed nine different analyses and only one resulted in significant gender bias. Indeed, we used a number of different specifications (discrete, continuous, and errors) yet the main result remained the same. We therefore conclude that there is no gender bias in overconfidence in our sample with the exception of out-group overplacement in the RPM test.

Interestingly, we did not find any gender bias in the task where participants had no previous experience. In contrast, we observed (small) gender differences in the task where participants did have previous experience and prior knowledge. Our study therefore supports the idea that observed overplacement might be partially explained by gender biased personal experience. Supporting this conjecture, we observed that the only case were we found strong gender differences is due to erroneous predictions of others' performances and is not related to overconfidence regarding one's own performance.

It is important to mention that this study has two serious limitations. First, there is a potential problem of low statistical power since our sample size is relatively small. With only 120 participants, it might be the case that there is not enough power to detect minor effects. This is an issue that we cannot address with this dataset. Second, all our participants faced the very same question sequence and we cannot eliminate the possibility of order effects. However, it is important to highlight that the environment was feedback free (participants did not receive any information during the six tasks). Moreover, we did not observe participants make erratic predictions in the final stage due to inattention given that the predictions look quite consistent across the entire experiment. Both issues may represent a potential threat to the validity of this research and require further investigation.

\section{References}

Alicke, M.D., Govorun, O., 2005. The better-than-average effect. The Self in Social Judgment, 1, 85-106.

Antecol, H., 2000. An examination of cross-country differences in the gender gap in labor force participation rates. Labour Economics, 7(4), 409-426.

Antecol, H., 2001. Why is there interethnic variation in the gender wage gap? The role of cultural factors. Journal of Human Resources, 119-143. 
Barber, B.M., Odean, T., 2001. Boys will be boys: Gender, overconfidence, and common stock investment. The Quarterly Journal of Economics 116(1): 261-292.

Benabou, R., Tirole, J., 2002. Self-Confidence and Personal Motivation. The Quarterly Journal of Economics, 117(3), 871-915.

Biais, B., Hilton, D., Mazurier, K., Pouget, S., 2005. Judgemental overconfidence, selfmonitoring, and trading performance in an experimental financial market. The Review of Economic Studies, 72(2), 287-312.

Brañas-Garza, P., Estepa, L., Jorrat, D.A., Orozco, V., Rascón Ramírez, E., 2020. To pay or not to pay: Measuring risk preferences in lab and field. Mimeo.

Brañas-Garza, P., Kujal, P., Lenkei, B., 2019. Cognitive reflection test: Whom, how, when. Journal of Behavioral and Experimental Economics 82: 101455.

Bucher-Koenen, T., Alessie, R., Lusardi, A., Van Rooij, M., 2016. Women, confidence, and financial literacy. Mimeo.

Cabrera, J.M., Cid, A., 2017. Gender differences to relative performance feedback: A field experiment in education. Universidad de Montevideo wpaper 1704.

Compte, O., Postlewaite, A., 2004. Confidence-enhanced performance. The American Economic Review, 94(5), 1536-57.

Dahlbom, L., Jakobsson, A., Jakobsson, N., Kotsadam, A., 2011. Gender and overconfidence: are girls really overconfident? Applied Economics Letters, 18(4), 325327.

Deaves, R., Lüders, E., Luo, G.Y., 2009. An experimental test of the impact of overconfidence and gender on trading activity. Review of Finance, 13(3), 555-575.

De Bondt, W.F., Thaler, R.H., 1995. Financial decision-making in markets and firms: A behavioral perspective. In: Handbook in Operations Research and Management Science, Vol. 9, 385-410.

Frederick, S., 2005. Cognitive reflection and decision making. Journal of Economic Perspectives, 19(4):25-42.

Gneezy, U., Niederle, M., Rustichini, A., 2003. Performance in competitive environments: Gender differences. The Quarterly Journal of Economics, 118(3), 10491074. 
Gneezy, U., Leonard, K.L., List, J.A., 2009. Gender differences in competition: Evidence from a matrilineal and a patriarchal society. Econometrica, 77(5), 1637-1664. Healy, A., Pate, J., 2007. Overconfidence, social groups, and gender: Evidence from the lab and field. https://ssrn.com/abstract $=934320$

Hedges L.V., Nowell A., 1995. Sex Differences in mental test Scores, variability, and numbers of high-scoring individuals. Science 269: 41-45.

Holt, C.A., Laury, S.K., 2002. Risk aversion and incentive effects. The American Economic Review, 92(5):1644-1655.

Hyde J., Lindberg S., Linn M., Ellis A., Williams C., 2008. Gender similarities characterize math performance. Science 321: 494-495.

Jakobsson, N., Levin, M., Kotsadam, A., 2013. Gender and overconfidence: effects of context, gendered stereotypes, and peer group. Advances in Applied Sociology, 3(02), 137.

Johnson, D.D., 2009. Overconfidence and war. Harvard University Press.

Kanter, R.M., 2004. Confidence: How Winning Streaks and Losing Streaks Begin and End. New York, NY: Crown Business.

Moore, D.A., Healy, P.J., 2008. The trouble with overconfidence. Psychological Review, 115(2), 502.

Moore, D. A., \& Dev, A.S., 2018. Individual differences in overconfidence. In: V. Zeigler-Hill and T.K. Shackelford (Eds.), Encyclopedia of Personality and Individual Differences. New York: Springer.

Muthukrishna, M., Henrich, J., Toyokawa, W., Hamamura, T., Kameda, T., Heine, S.J., 2018. Overconfidence is universal? Elicitation of Genuine Overconfidence (EGO) procedure reveals systematic differences across domain, task knowledge, and incentives in four populations. PLoS ONE 13(8), e0202288.

Nekby, L., Thoursie, P. S., Vahtrik, L., 2008. Gender and self-selection into a competitive environment: Are women more overconfident than men?. Economics Letters, 100(3), 405-407.

Neyse, L., Bosworth, S., Ring, P., Schmidt, U., 2016. Overconfidence, Incentives and Digit Ratio. Scientific Reports, 6 (1) 
Niederle, M., Vesterlund, L., 2007. Do women shy away from competition? Do men compete too much? The Quarterly Journal of Economics, 122(3), 1067-1101.

Odean, T., 1999. Do Investors Trade Too Much? The American Economic Review, 89(5), 1279-1298.

Raven, J.C., 1936. Mental tests used in genetic studies: the performances of related individuals in tests tainly educative and mainly reproductive. M.Sc. Thesis, University of London.

Ring, P., Neyse, L., David-Barett, T., \& Schmidt, U., 2016. Gender differences in performance predictions: evidence from the cognitive reflection test. Frontiers in Psychology 7: 1680.

Soll, J.B., Klayman, J., 2004. Overconfidence in interval estimates. Journal of Experimental Psychology: Learning, Memory, and Cognition, 30(2), 299.

Taylor, S.E., Kemeny, M.E., Reed, G.M., Bower, J.E., Gruenewald, T.L., 2000. Psychological resources, positive illusions, and health. American Psychologist, 55(1), 99.

Zhang, Y., Xu, Z., Palma, M.A., 2019. Conveniently dependent or naively overconfident? An experimental study on the reaction to external help. PlOS One, 14(5), e0216617. 


\section{Appendix 1: Figures and tables}

Figure A1: Raven Test: in-group (top) \& out-group (bottom)
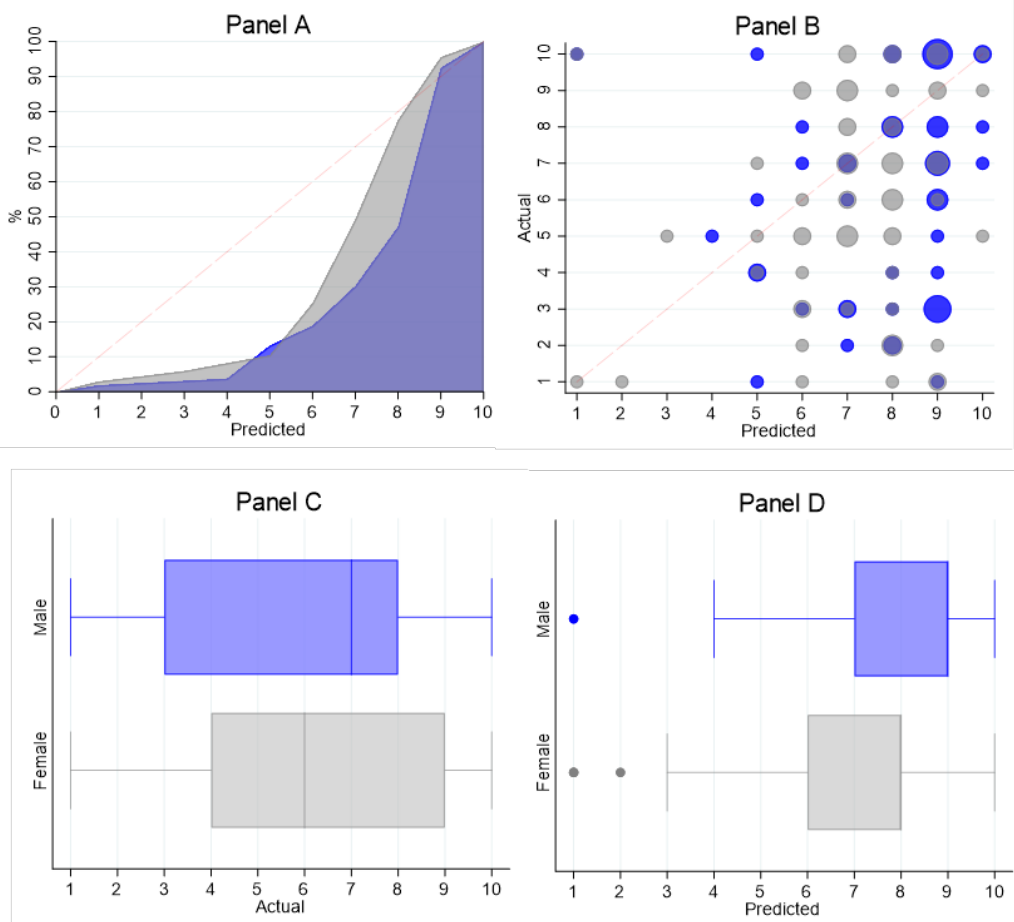

$\square$ Male $\square$ Female
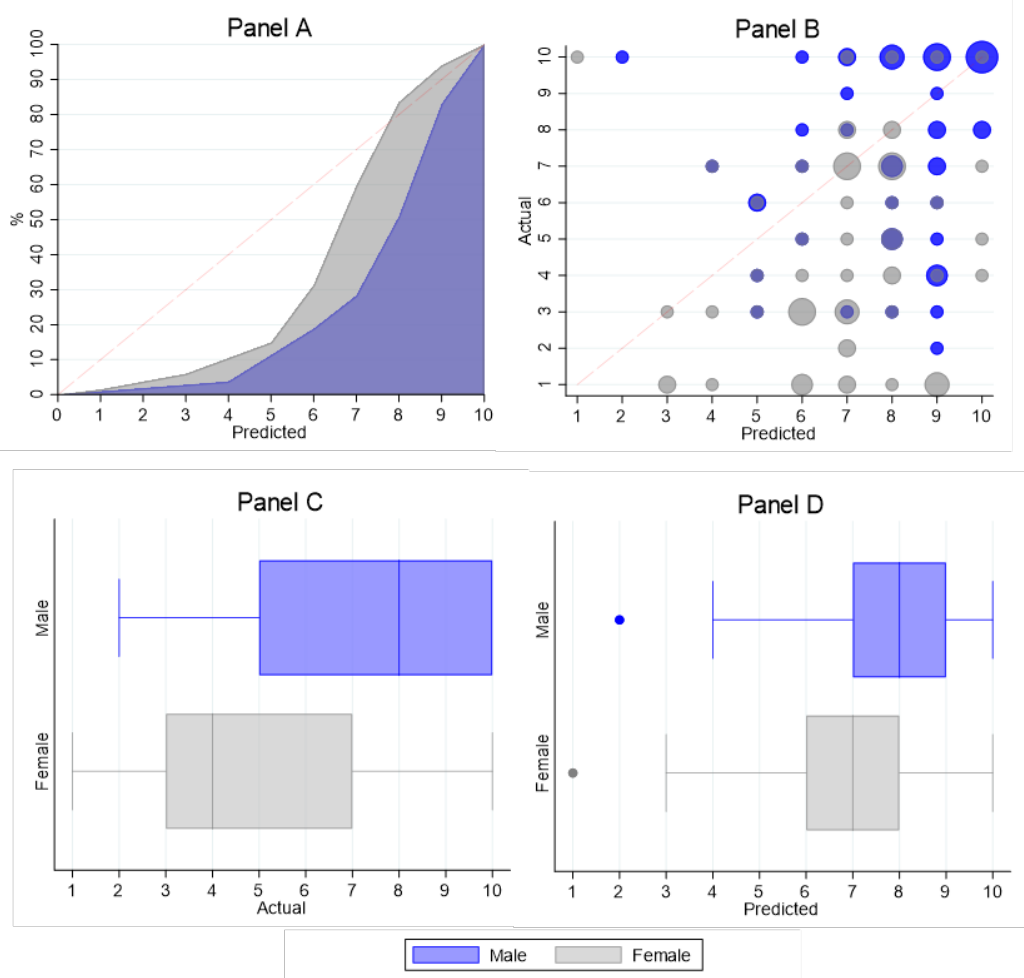
Figure A2: Video Task: in-group (top) \& out-group (bottom)
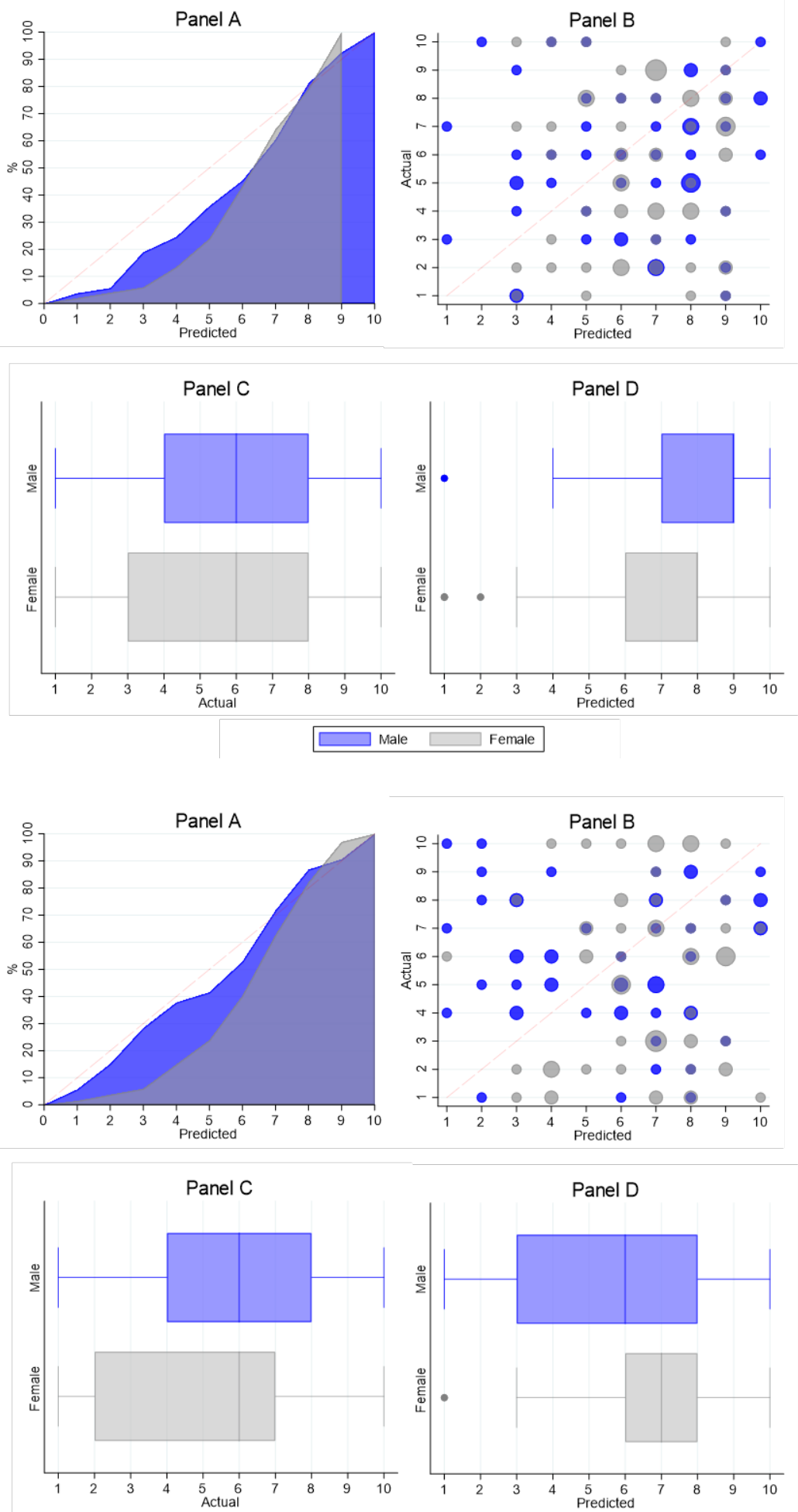

Panel D

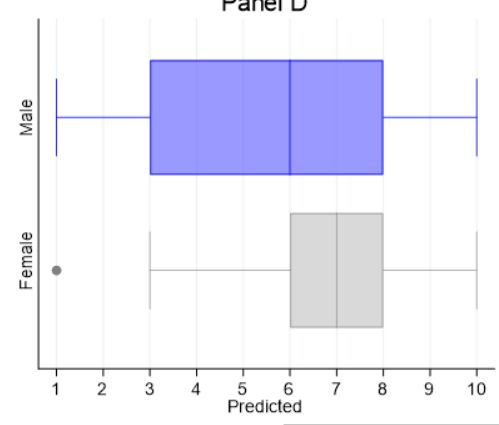

Male $\square$ Female 
Table A1: Gender differences in overplacement in the Raven test (discrete $>1$ decile)

\begin{tabular}{|c|c|c|c|c|c|c|}
\hline \multirow{2}{*}{$\begin{array}{l}\text { Model } \\
\text { Specification }\end{array}$} & \multicolumn{2}{|c|}{ Full sample } & \multicolumn{2}{|c|}{ In-Group } & \multicolumn{2}{|c|}{ Out-group } \\
\hline & (1) & (2) & (1) & (2) & (1) & (2) \\
\hline \multirow[t]{2}{*}{ Female } & $0.206^{*}$ & $0.192 *$ & -0.073 & -0.067 & $0.257 * *$ & $0.262 * *$ \\
\hline & $(0.089)$ & $(0.1)$ & $(0.092)$ & $(0.097)$ & $(0.09)$ & $(0.095)$ \\
\hline \multirow[t]{2}{*}{ Age } & & 0.017 & & 0.031 & & 0.035 \\
\hline & & $(0.02)$ & & $(0.021)$ & & $(0.021)$ \\
\hline \multirow[t]{2}{*}{ Averse } & & 0.041 & & 0.057 & & 0.024 \\
\hline & & $(0.03)$ & & $(0.033)$ & & $(0.032)$ \\
\hline \multirow[t]{2}{*}{ CRT } & & -0.13 & & -0.058 & & -0.117 \\
\hline & & $(0.08)$ & & $(0.084)$ & & $(0.083)$ \\
\hline \multirow[t]{2}{*}{ Health } & & 0.067 & & 0.063 & & 0.024 \\
\hline & & $(0.06)$ & & $(0.059)$ & & $(0.057)$ \\
\hline \multirow[t]{2}{*}{ Constant } & $0.302 * * *$ & -0.46 & $0.491 * * *$ & -0.685 & $0.340 * * *$ & -0.594 \\
\hline & $(0.067)$ & $(0.54)$ & $(0.069)$ & $(0.558)$ & $(0.067)$ & $(0.547)$ \\
\hline Observations & 120 & 120 & 120 & 120 & 120 & 120 \\
\hline R-squared & 0.043 & 0.099 & 0.005 & 0.067 & 0.065 & 0.11 \\
\hline
\end{tabular}

Note: The dependent variable is equal 1 if overplacement in the raven test in more than 1 decile, and 0 otherwise. Standard errors in parentheses. $\mathrm{p}<0.001, * * \mathrm{p}<0.01, * \mathrm{p}<0.05$ 
Table A2: Gender differences in overplacement in the Video task (discrete $>1$ decile)

\begin{tabular}{lcccccc}
\hline \multirow{2}{*}{$\begin{array}{l}\text { Model } \\
\text { Specification }\end{array}$} & \multicolumn{2}{c}{ Full sample } & \multicolumn{2}{c}{ In-Group } & \multicolumn{2}{c}{ Out-group } \\
\cline { 2 - 7 } Female & $\mathbf{( 1 )}$ & $\mathbf{( 2 )}$ & $\mathbf{( 1 )}$ & $\mathbf{( 2 )}$ & $\mathbf{( 1 )}$ & $\mathbf{( 2 )}$ \\
& 0.116 & 0.108 & 0.029 & 0.021 & 0.164 & 0.189 \\
Age & $(0.089)$ & $(0.1)$ & $(0.092)$ & $(0.1)$ & $(0.091)$ & $(0.1)$ \\
& & -0.02 & & 0 & & 0.018 \\
Averse & & $(0.02)$ & & $(0.02)$ & & $(0.02)$ \\
& & 0.042 & & 0.052 & & 0.025 \\
CRT & & $(0.03)$ & & $(0.03)$ & & $(0.03)$ \\
& & 0.148 & & -0.03 & & -0.07 \\
Health & & $(0.08)$ & & $(0.09)$ & & $(0.08)$ \\
& & 0.017 & & 0.093 & & 0.112 \\
& & $(0.06)$ & & $(0.06)$ & & $(0.06)$ \\
Constant & $0.302 * * *$ & 0.404 & $0.434 * *$ & -0.12 & $0.358 * * *$ & -0.55 \\
& $(0.066)$ & $(0.55)$ & $(0.069)$ & $(0.57)$ & $(0.068)$ & $(0.56)$ \\
& & & & & & 120 \\
Rbservations & 120 & 120 & 120 & 120 & 120 & 120 \\
\hline Note: Thuared & 0.014 & 0.05 & 0.001 & 0.043 & 0.027 & 0.069 \\
\hline
\end{tabular}

Note: The dependent variable is equal 1 if overplacement in the video task in more than 1 decile, and 0 otherwise. Standard errors in parentheses. $* * *$ $\mathrm{p}<0.001, * * \mathrm{p}<0.01, * \mathrm{p}<0.05$ 


\section{Appendix 2: Protocol for Video task and scoring.}

On April 20th 2009, the 191 subjects participating in the study performed a series of computerized task including risk aversion tests, raven etc. (see Brañas-Garza \& Rustichini 2009 for details). 188 completed both tasks.

The video session was individualized: each subject came to one room where he has to read a sentence "My name is $x x x x$ and I was born at xxx. My code is xxx". All the experimental subjects did the exact same task with the only difference of illumination (changing across the morning due to clouds). The video session was conducted by a professional.

All the participants are undergraduate students in Business or Economics in the last courses of their degree (average age is 22)

During the months of September to December 2009 several rating sessions where organized ( 3 or 4 subjects each). We completed 20 individual evaluations of the videos (10 females-voters +10 males-voters).

The referees visualized the videos three times following a random sorting. Referees were asked to answer, for each video, the following questions:

- Do you consider that he/she is Beauty? yes $(=1)$, not $(=0)$

- Did you like his/her performance? yes $(=1)$, not $(=0)$

Note that both the presentation and the order of the questions were random. Referees where emphasized that at each time they should answer to the question only, that is, at the time of the beauty questions they don't have to evaluate subject performance, etc. Once they have already finished the where to ask a final question:

- Independently you consider him beauty or you liked his performance, do you feel sympathy toward him/her? yes $(=1)$, not $(=0)$

The last questions intended to capture the special feelings that some people transmit.

All the referee are master students in Business or Economics (average age is 25). Regarding referees' nationalities we have: women: Colombia, UK, Greece (3), Venezuela, Hong-kong, Spain (2), Romania; men: Colombia (2), Albania, Venezuela, Germany, Bolivia, Vietnam, Greece (2), Spain.

For each individual we compute:

- Beauty $\left(b_{i} \in[0,10]\right)$ : the number of votes he/she obtains regarding his/her physical presence.

- Performance $\left(p_{i} \in[0,10]\right)$ : the number of votes he/she obtains.

- Sympathy $\left(s_{i} \in[0,10]\right)$ : the number of votes he/she obtains. 


\title{
Appendix 3: Experimental instructions
}

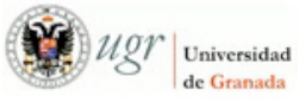

\author{
The Granada Lab of Behavioral
}

Economics(GLOBE)

\section{TAREA 1}

Queremos que nos indiques el tramo en el que tú piensas que te encuentras en el test de Raven.

Por ejemplo, si piensas que estás entre el $40 \%$ con la puntuación más alta, pero por debajo del $30 \%$ con la puntuación más alta, deberás señalar el tramo $(61,70)$. Si piensas que estás entre el $20 \%$ con la puntuación más alta pero no entre el $10 \%$ con la puntuación más alta, deberás señalar el tramo $(81,90)$. Por el contrario si crees que no lo has hecho demasiado bien debes de mirar a la parte izquierda de la distribución. Si crees que estás dentro del grupo de los que lo han hecho francamente mal (los "peores") debes elegir el tramo $(0,10)$. Justo lo contrario debes de señalar $(91,100)$ si piensas que eres de los que lo han hecho mejor de todos.

Por favor, elije el tramo en el que te clasificas. Ten en CUENTA QUE si el tramo que señalas coincide con el tramo en el que realmente te encuentras, entonces ganarás 20 Euros.

\begin{tabular}{|c|c|c|c|c|c|c|c|c|c|}
\hline$(0,10)$ & $(11,20)$ & $(21,30)$ & $(31,40)$ & $(41,50)$ & $(51,60)$ & $(61,70)$ & $(71,80)$ & $(81,90)$ & $(91,100)$ \\
\hline
\end{tabular}

\section{TASK 1}

We want you to indicate in which interval of the Raven test you think you are.

For instance, if you think you are among the $40 \%$ with the highest grade, but below the $30 \%$ with the highest grade, you should select the interval $(61,70)$. If you think you are between the $20 \%$ with the highest grade but not among the $10 \%$ with the highest grade, you should select the interval $(81,90)$. Otherwise, if you think you have not done the test very well, you should look at the left of the distribution. If you think you are within the group that did it frankly bad (the worst), you should select the interval $(0,10)$. On the contrary, if you think you are among the best, you should select the interval $(91,100)$.

Please, choose the interval in which you qualify. PLEASE NOTE that if the interval you indicate matches the interval you are actually in, then you will earn 20 euros. 
U Or Universidad de Granada
The Granada Lab of Behavioral

Economics(GLOBE)

\section{TAREA 2}

Queremos que nos indiques el tramo en el que tú piensas que te encuentras en la prueba de Video entre los (casi) 200 sujetos que participasteis. Recuerda que nuestros expertos han valorado el Aplomo, la Imagen y la Calidad de la expresión oral y que han puntuado todos los vídeos; lo cual nos ha permitido sacar un ranking de todos los sujetos. Igual que en el caso anterior, piensa en cómo crees que hiciste dicha prueba, como crees que lo habrán hecho los demás. Como en el caso anterior queremos que posiciones tu actuación (tu prueba del video) sobre el total de la población que participó.

Por favor, elije el tramo en el que te clasificas. Ten en CUENTA QUE si el tramo que señalas coincide con el tramo en el que realmente te encuentras, entonces ganarás 20 Euros.

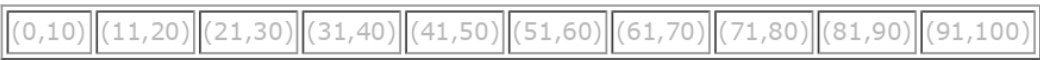

\section{TASK 2}

We want you to indicate in which interval you think you are on the video task among the (almost) 200 individuals that participated. Remember that our experts have evaluated the poise, the image and the quality of the oral expression and that all the videos have been rated; which has allowed us to draw a ranking of all subjects. Like in the previous case, think about how you think you and others did this test. As in the previous case, we want you to position your performance (in the video task) over the total population that participated.

Please, choose the interval in which you qualify. PLEASE NOTE that if the interval you indicate matches the interval you are actually in, then you will earn 20 euros. 
Ugr Universidad de Granada
The Granada Lab of Behavioral

Economics(GLOBE)

\section{TAREA 3}

Piensa ahora sólo en la Población de Mujeres que participaron en la prueba (algo más de 100). Queremos que te compares con ellas. Sólo con ellas.

Ahora piensa en el test de Raven. Queremos que nos digas en el tramo en el que crees que te encuentras si solo tienes en cuenta el resultado obtenido por las mujeres. Es decir, si de la población que hizo el test, quitamos a los hombres, señala la posición en la que piensas que te encuentras.

Por favor, elije el tramo en el que te clasificas. Ten en CUENTA QUE si el tramo que señalas coincide con el tramo en el que realmente te encuentras, entonces ganarás 20 Euros.

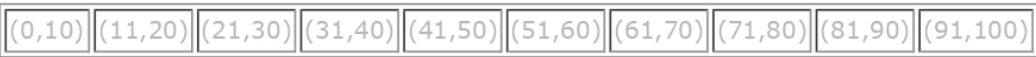

\section{TASK 3}

Now, think only about the population of women who participated in the test (just over 100). We want you to compare yourself with them. Only with them.

Now, think about the Raven test. We want you to tell us the interval in which you think you are if you only take into account the result obtained by women. That is, if we remove men from the population that took the test, indicate the position in which you think you are.

Please, choose the interval in which you qualify. PLEASE NOTE that if the interval you indicate matches the interval you are actually in, then you will earn 20 euros. 
Ugr $\left.\right|_{\text {Universidad }}$ de Granada
The Granada Lab of Behavioral

Economics(GLOBE)

\section{TAREA 4}

Piensa ahora sólo en la Población de Mujeres que participaron en la prueba (algo más de 100). Queremos que te compares con ellas. Sólo con ellas.

Ahora piensa en la prueba de Video. Queremos que nos digas en el tramo en el que crees que te encuentras si solo tienes en cuenta las presentaciones realizadas por mujeres. Es decir, si de la población que hizo la prueba, quitamos a los hombres, señala la posición en la que piensas que te encuentras.

Por favor, elije el tramo en el que te clasificas. Ten en CUENTA QUE si el tramo que señalas coincide con el tramo en el que realmente te encuentras, entonces ganarás 20 Euros.

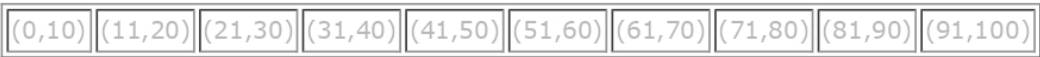

\section{TASK 4}

Now, think only about the population of women who participated in the test (just over 100). We want you to compare yourself with them. Only with them.

Now, think about the video task. We want you to tell us the interval in which you think you are if you only take into account the result obtained by women. That is, if we remove men from the population that took the test, indicate the position in which you think you are.

Please, choose the interval in which you qualify. PLEASE NOTE that if the interval you indicate matches the interval you are actually in, then you will earn 20 euros. 
ugr Universidad de Granada
The Granada Lab of Behavioral

Economics(GLOBE)

\section{TAREA 5}

Piensa ahora sólo en la Población de Hombres que participaron en la prueba (algo menos de 100). Queremos que te compares con ellos. Sólo con ellos.

Ahora piensa en el test de Raven. Queremos que nos digas en el tramo en el que crees que te encuentras si sólo tienes en cuenta el resultado obtenido por los hombres. Es decir de la población que hizo la prueba quitamos a las mujeres. Señala la posición en la que piensas que te encuentras.

Por favor, elije el tramo en el que te clasificas. Ten en CUENTA QUE si el tramo que señalas coincide con el tramo en el que realmente te encuentras, entonces ganarás 20 Euros.

\begin{tabular}{|c|c|c|c|c|c|c|c|}
\hline$(0,10)$ & $(11,20)$ & $(21,30)$ & $(31,40$ & $(41,50$ & $(51,60$ & $(61,70)$ & 718 \\
\hline
\end{tabular}

\section{TASK 5}

Now, think only about the population of men who participated in the test (just over 100). We want you to compare yourself with them. Only with them.

Now, think about the Raven test. We want you to tell us the interval in which you think you are if you only take into account the result obtained by men. That is, if we remove women from the population that took the test, indicate the position in which you think you are.

Please, choose the interval in which you qualify. PLEASE NOTE that if the interval you indicate matches the interval you are actually in, then you will earn 20 euros. 
U $\mathrm{gr}$ Universidad de Granada
The Granada Lab of Behavioral

Economics(GLOBE)

\section{TAREA 6}

Piensa ahora sólo en la Población de Hombres que participaron en la prueba (algo menos de 100). Queremos que te compares con ellos. Sólo con ellos.

Ahora piensa en la prueba de Video. Queremos que nos digas en el tramo en el que crees que te encuentras si solo tienes en cuenta las presentaciones realizadas por hombres. Es decir, si de la población que hizo la prueba, quitamos a las mujeres, señala la posición en la que piensas que te encuentras.

Por favor, elije el tramo en el que te clasificas. Ten en CUENTA QUE si el tramo que señalas coincide con el tramo en el que realmente te encuentras, entonces ganarás 20 Euros.

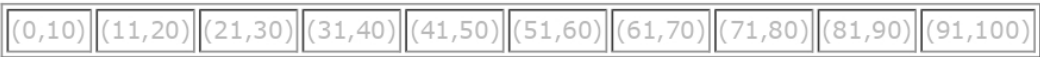

\section{TASK 6}

Now, think only about the population of men who participated in the test (just over 100). We want you to compare yourself with them. Only with them.

Now, think about the video task. We want you to tell us the interval in which you think you are if you only take into account the result obtained by men. That is, if we remove women from the population that took the test, indicate the position in which you think you are.

Please, choose the interval in which you qualify. PLEASE NOTE that if the interval you indicate matches the interval you are actually in, then you will earn 20 euros. 